\title{
Does The Hype Exceed The Reality For ERP Applications And Small Manufacturing Companies: A Case Study
}

Louis J. Zivic (E-mail: zivic@juno.com), Fitchburg State College

Timothy P. Shea (E-mail: tshea@umassd.edu), University of Massachusetts Dartmouth Michael Fuller (E-mail: mfuller@yorkmfg.com), York Manufacturing

\begin{abstract}
This case study describes the implementation of an ERP in a new arena - small manufacturing companies - and explores possible differences compared with successful implementations of ERP's in larger manufacturing companies. The company that was studied is a small manufacturing company in Maine (less than $\$ 10$ million in annual sales) that began implementing a small business ERP 12 months ago. Information was collected through interviews and the completion of a questionnaire based on the Stratman-Roth ERP Competence Scales (2002). Results suggest that while this company's ERP implementation has been more positive than negative, a small company's limited financial resources and lack of internal experience and expertise in large IT system projects add to the already complex challenges surrounding an ERP implementation.
\end{abstract}

\section{Introduction}

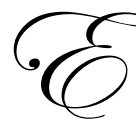

nterprise Resource Planning systems, or ERP's, have been implemented or are being implemented in many large companies around the world - especially manufacturing companies. While the definition of ERP varies, the following two definitions are useful:

- $\quad$ "ERP has been a software solution integrating the various functional spheres in an organization - a link through the entire supply chain, aimed at adapting best industry and management practices for providing the right product at the right place at the right time at least cost ... [Today], the challenge for ERP systems is to set up and integrate information resources across geographically spread business units to enable optimization across the organization." (Rao, 2000)

- $\quad$ MySAP Business Suite, SAP's ERP solution, "is a comprehensive family of solutions that provides best-ofbreed functionality, complete integration, unlimited scalability, and easy collaboration across business networks." (SAP, 2003)

As the ERP marketplace has matured, ERP vendors have expanded product offerings beyond large companies (originally, primarily manufacturing companies) and are also diffusing into mid-size (\$100 to $\$ 500$ million in annual sales) and even small companies (less than \$100 million in annual sales). (Morejon \& Gros, 2003; Sarkis \& Gunasekaran, 2003) A quick look at the web sites for major ERP vendors illustrates how they are emphasizing solutions across numerous industries as well as to the small and the mid size organizations. (SAP 2003, Peoplesoft 2003, Oracle 2003). Smaller companies are attracted because these new offerings are "less-expensive, modular, Web-architected, and hosted versions" of the more expensive versions of the package. (Greenemeier, 2001).

Mid and small businesses are seen as benefiting in two ways. First, the integration of data provides the same benefits as it would to a large company. Secondly, many small and mid sized businesses provide products and services to large corporations. The large companies, many with ERP systems in place that provide B2B and supply 
chain efficiencies, expect to have the same benefits available regardless of the size of the company they are working with.

However, the benefits for small and mid sized companies that implement an ERP are largely untested and assumed to be the same as for large companies. In fact, there is growing discussion that "the needs and operating requirements of [small and medium sized manufacturers] are very different from those of large companies." (Huin et. al., 2002, p. 771)

\section{Background - The Case}

York Manufacturing of Maine represents an early example of a very small manufacturing company, with under \$10 million in annual sales, working to implement an ERP system. "For over 60 years, York Manufacturing has been a leader in the manufacturing of copper laminated flashings for masonry work" (York, 2003). In December 2001 Michael Fuller was brought in as the new President of York Manufacturing.

After settling in, one of the first major projects Mr. Fuller focused on was to implement an ERP system. Why? As he put it, succinctly, "you can't manage what you can't measure". Put in other terms, there were three primary reasons that Mr. Fuller decided to implement an ERP system:

$\begin{array}{ll}- & \text { Measurement } \\ \text { - } & \text { Management \& Control } \\ \text { Process Improvement }\end{array}$

Improvement in each of these three areas would contribute to an increase in supply chain efficiency and the ability to lower York's costs. In addition, the belief was that implementing an ERP system would lead to superior management in all areas of the company. Ultimately, strong management would provide the foundation on which to grow. Growth was York's long-term goal.

More immediately, York wanted to get a better handle on its inventory. As a manufacturer, raw materials represent York's single largest costs. Previously, York had difficulty managing the procurement and the conversion of such material into finished goods. Much of York's inventory control and resource planning was done by the "walk around" method. Mr. Fuller clearly saw the benefit of being able to analyze and forecast product sales, manage raw material lead times from multiple vendors, and reduce inventory levels. An ERP would provide the necessary communication link between York's customers and vendors that would lead to improved supply chain efficiency.

Despite being a small cog in a giant supply chain, Mr. Fuller saw the long-range importance and benefits of ERP systems. Providing high quality, low cost products to York's customers in a timely manner, backed up with excellent customer service, could only improve York's top line growth. York's ability to forecast product sales, plan production and coordinate material procurement, could only improve York's cost structure. The coordination and integration of end-users with primary material suppliers would result in highly satisfied customers.

In August 2002, York started the ERP implementation process. The modules to be implemented included MRP, CRM, Basic Accounting (order entry, accounts payable, accounts receivable, and general ledger), and Business Intelligence.

\section{Data Collection}

Data collection was a single case, with York Manufacturing, and incorporated both unstructured interviews with the President and the application of the Stratman-Roth ERP Competence Scales (Stratman \& Roth, 2002) through a questionnaire filled out by the President. A condensed version of the questionnaire, containing the questions asked, is attached as the Appendix. Data was collected during July and August 2003, one year after the beginning of the ERP implementation. 
Stratman \& Roth (2002) offer an interesting set of tested constructs related to ERP competence. ERP competence is defined as "a portfolio of managerial, technical, and organizational skills and expertise posited as antecedents to improved business performance occurring after an ERP system is operational and functionally stable.” (p. 601) The eight scales include technical elements (project management and IT skills), managerial elements (strategic IT planning and executive commitment), and organizational elements (business process skills, ERP training, learning, and change readiness). More specifically, the eight scales are designed to measure an organization's competence in: (Stratman \& Roth, 2002)

- $\quad$ Project Management: The use of skills and knowledge in coordinating the scheduling and monitoring of defined activities to ensure that the stated objectives of implementation projects are achieved.

- IT Skills: The ability to configure and maintain information systems in support of the business.

- Strategic IT Planning: Matching IT capabilities with the changing, cross-functional business requirements of the enterprise.

- $\quad$ Executive Commitment: Top management's willingness to champion ERP within the organization, and allocate the resources required for successful ERP infusion.

- Business Process Skills: An understanding of how the business operates, and the ability to predict the impact of a particular decision or action on the rest of the enterprise.

- $\quad$ ERP Training: The processes involved in teaching each of the various user groups to use the ERP system efficiently in their day-to-day activities.

- Learning: Activities designed to identify cutting-edge ERP techniques from both internal and external sources.

- Change Readiness: Managerial strategies used to overcome workforce resistance to the operational changes resulting from the implementation of the ERP system.

These eight scales were developed and validated and "are hypothesized to be associated with successful ERP adoption" (p. 601), measured as improved business performance.

\section{Analysis}

Mr. Fuller, upon reflection on the last twelve month's ERP implementation process, concluded that several constraints within his company made the implementation process more difficult. First, as a small business, York's resources are limited. Often York employees are called on to wear many hats. In such an environment, specific expertise in certain areas was scarce - IT project design and project management (especially large project experience) in general and ERP implementation, specifically (including manufacturing and cost accounting systems). For this reason, York relied heavily on their accountants, consultants as well as other outsourced partners. Coordinating the project became a full time job and typically fell on the shoulders of Mr. Fuller, the President of the company.

The lack of experience in IT systems design and implementation caused problems from the beginning. York spent a great deal of time selecting the appropriate vendor and very little time planning and coordinating the implementation. For this reason, a significant amount of groundwork that should have been completed prior to the implementation was started during the implementation, and often in an ad-hoc, as-needed fashion. For example, setting up the Bill's of Material, product configurations, and other general parameters could have and should have been done as part of the design phase, in advance of York's implementation, and, in fact, before the evaluation and selection of the ERP package and vendor.

Other problems arose with unexpected complications in the implementation. For example, the conversion of data from York's existing accounting system to the new ERP system was not a problem during the initial consultation. However, when it came time to do the actual conversion York was informed of additional costs not previously discussed. Additional complications arose regarding system configurations and technology. Recently, an additional server was deemed necessary and had to be purchased and installed. This system requirement should have been completed during the initial configuration. Overall, York's costs were much higher than expected. 
The results from the Stratman-Roth Competence Scale questionnaire support and also flesh out the previous comments. A summary of the results of the average scores for each scale is provided in Table I, rank ordered. The top three ranked scales - Executive Commitment (4.6), Learning (4.5), and Change Readiness (4.2) are those items most under the direct influence of the President of the company who has been the primary champion of the project. The next tier of ranked scales - Project Management (3.9), Strategic IT Planning (3.7), and Business Process Skills (3.6) - all show average results, neither positive nor negative. The lack of sufficient skills in these three areas all contributed to the sense - a year after implementation of the ERP began -- of not having done enough internal design work before engaging the vendors which resulted in doing some basic design work "on the fly" (such as setting up the Bill's of Material) and some surprises (such as requiring an additional server). The final two scales ranked poorly - ERP Training (2.8) and IT Skills (1.9). The poor ERP Training score primarily reflects a naiveté or inexperience with how much training would be necessary. The lack of large project IT skills (both design and implementation) contributed to the lack of planning up front and a misplaced trust in vendor regarding items such as estimated time for data conversion. These are easy judgments to make in hindsight but represent examples of how a small manufacturing company that is leapfrogging from an IS system that is primarily an accounting system to a multiple module, integrated ERP system needs to locate and incorporate experienced personnel in order to help bridge the gap and provide guidance. However, the question then becomes one of available resources -- especially money. A small company does not normally have the reserves a large company has to either heavily invest in consultants or absorb significant, unexpected costs along the way. The idea of "financial readiness" is one area the Stratman-Roth Competence Scales does not cover.

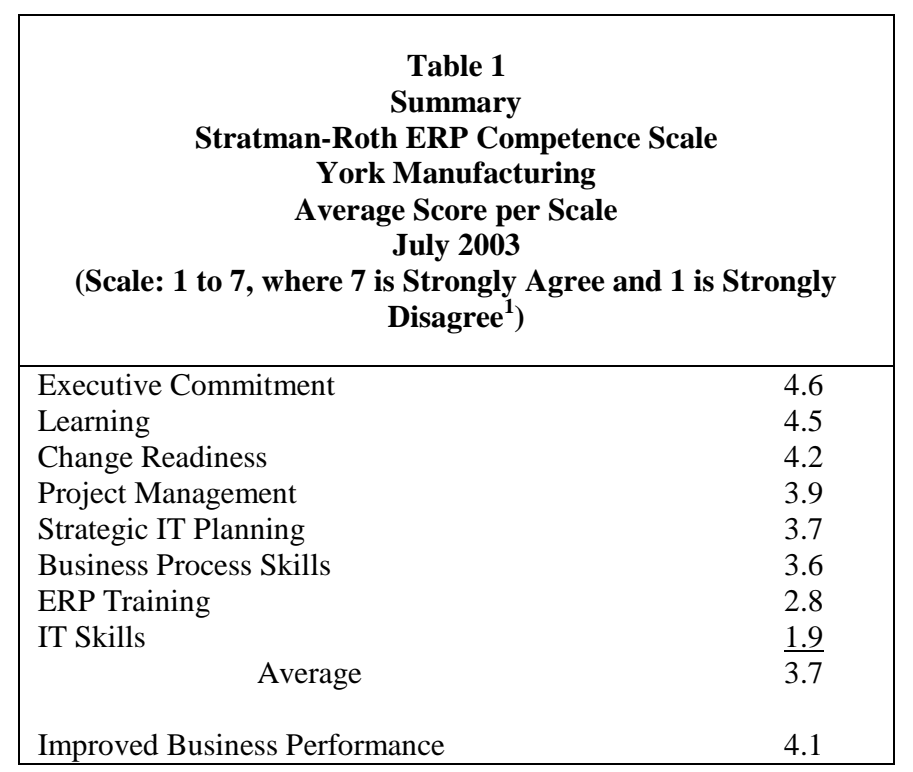

In spite of the limitations in York's "readiness" to implement an ERP, York perceives that their initial expected benefits have been realized or will be realized in the future. This perception is reflected in the Improved Business Performance Scale result of 4.1, which is a positive result, and quite a bit higher than the overall average of the eight individual readiness scales (3.7).

\section{Conclusion}

Results suggest that York's ERP implementation has been more positive than negative. The net positive results are most likely due to the inherent potential benefits of the ERP system and the personal commitment and

1 Several questions were recoded during analysis to make the scaling consistent (e.g., positive results vs. negative result). 
sponsorship of Mr. Fuller, as President and Project Leader. This commitment helped to bring the company's limited financial resources to bear on the problems they encountered as well as overcome the lack of internal experience and expertise in designing, implementing, and managing large IT system projects, especially ERP projects. These constraints, which may be typical of many small companies, added to the already complex challenges surrounding an ERP implementation. Overall, this case study suggests that other ERP implementations in small businesses need to be evaluated in order to better understand how ERP systems can best be applied in this new arena and that, with the exception of financial readiness, the Stratman-Roth ERP Competence Scale was very useful in documenting a small manufacturing company's readiness for an ERP implementation.

\section{References}

1. Greenemeier, Larry, “ERP: It's not just for big companies”, Information Week, October 29, 2001, p. 52.

2. Huin, S. F., L. H. S. Luong, and K. Abhary. "Internal supply chain planning determinants in small and medium-sized manufacturers", International Journal of Physical Distribution \& Logistics Management, Vol. 32, Iss. 9/10, pp. 771+.

3. Morejon, Mario and Michael Gros, "SMB manufacturing arena ripe for new ERP solutions", CRN, Jul 14 2003, p.54.

4. $\quad$ Oracle, $\underline{w w w . o r a c l e . c o m}$, Oracle company web site, September 2003.

5. Rao, Siriginidi Subba, "Enterprise resource planning: business needs and technologies", Industrial Management + Data Systems, Vol. 100, Iss. 2, pp. 81+.

6. SAP, www.sap.com, SAP company web site, September 2003.

7. Sarkis, J. and A. Gunasekaran. "Enterprise resource planning - modeling and analysis", European Journal of Operational Research, Vol. 145, Iss. 2, April 16, 2003, pp. $229+$.

8. Stratman, Jeff, and Aleda Roth. "Enterprise resource planning (ERP) competence constructs: two-stage multi-item scale development and validation", Decision Sciences, Vol. 33, No. 4, Fall 2002, pp. 601-628.

9. York Manufacturing, www.yorkflashings.com, York Manufacturing company web site, July 2003.

\section{Appendix \\ ERP Competence Scales}

Please answer the following questions by circling the appropriate number where "1" means Disagree and "7" means Agree.

Note: "ERP Entity" refers to those parts of the enterprise which have been impacted by the ERP system

\section{A. Background}

1. When did you begin your ERP implementation?

2. Have you completed your ERP implementation?

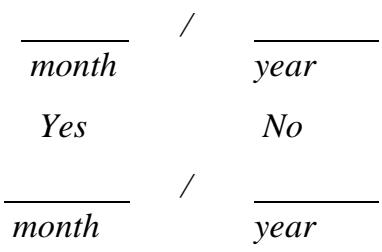

3. In general, please describe the modules / components that are contained in your ERP implementation.

\section{B. Strategic IT Planning}

***Timeframe: at the time the company committed to implement an ERP***

1. We constantly review out IT capabilities against strategic goals

2. IT plans are redesigned as required to meet evolving conditions

3. Strategic IT planning is a continuous process

4. Written guidelines exist to structure strategic IT planning in our organization.

5. Top management is not involved in strategic IT planning (Note the "not") 
6. Strategic IT planning includes inputs from all functional areas

C. Executive Commitment

***Timeframe: at the time the company committed to implement an ERP***

1. The need for long-term ERP support resources is recognized by management.

2. Executive management is enthusiastic about the possibilities of ERP.

3. Executives have invested the time needed to understand how ERP will benefit the enterprise.

4. Executives mandate the ERP requirements have priority over unique functional concerns.

5. Top management has clearly defined the ERP Entity's business goals

6. All levels of management support the overall goals of the ERP Entity.

***Timeframe: Four months into the ERP implementation***

7. Functional managers willingly assign resources to the ERP project, as they are needed.

\section{Project Management}

***Timeframe: Four months into the ERP project ***

0 . What was the title of the ERP project leader before becoming the ERP project leader?

1. The tasks to be performed during the ERP project are clearly defined

2. The responsibilities of project team members are clearly defined

3. There is a formal management process to track external contractor activities

4. Problems found during reviews of external project members are not tracked to closure (Note the "not")

5. Measurements are used to determine the status of project tasks

6. $\quad$ Project tasks are reviewed on a periodic basis.

7. The ERP project leader is able to track project tasks to completion

8. The ERP project leader is experienced in project management

\section{E. IT Skills}

*** Timeframe: at the time the company committed to implement an ERP $* * *$

0. How many full-time equivalent IT staff do you employ (including part-time people and consultants?

1. The internal IT staff has the ability to conduct routine ERP system maintenance.

2. There is a high degree of technical expertise in the IT organization

3. The database administrator is an expert in the ERP database management system.

4. Internal IT team members understand custom ERP software programs

5. The IT staff is able to efficiently implement ERP system upgrades

6. The IT staff has the technical ability to conduct a formal validation of all system changes.

7. IT staff is able to analyze the technical impact of proposed system changes

8. The IT staff actively builds relationships with business managers.

9. IT staff offers ideas on how IT can be used to achieve business goals.

10. IT staff communicates with functional user groups in the ERP Entity

11. The IT organization provides a service to the business

\section{F. Business Process Skills}

*** Timeframe: at the time the company committed to implement an ERP ***

1. There is a high level of business process knowledge within the ERP Entity

2. Functional managers are able to document cross-functional business process flows.

3. Business process design is driven by customer requirements

4. Managers are skilled at analyzing business processes for customer benefits

*** Timeframe: Four months into the ERP project *** 
5. Managers are not clear on how ERP-focused business processes support the goals of the ERP Entity.

*** Timeframe: two months after the ERP has been implemented ***

6. Employees understand how their actions impact the operations of other functional areas

7. Employees understand how their daily business activities support the goals of the ERP Entity.

8. The operational processes of the ERP Entity are formally documented.

9. Our ERP Entity's business process documentation reflects actual operational activities

\section{G. ERP Training}

*** Timeframe: two months after the ERP has been implemented ***

1. Specific user training needs were identified early in the project

2. A formal training program has been developed to meet the requirements of ERP system users.

3. Training materials have been customized for each specific job.

4. We seldom update training materials to reflect system changes.

5. Training materials target the entire business task, not just the ERP screens and reports.

6. Employees are tracked to ensure that they have received the appropriate ERP system training.

7. All users have been trained in basic ERP system skills

8. ERP system training review sessions are scheduled

\section{H. Learning}

*** Timeframe: six months after the ERP has been implemented (Skip to next section if your ERP has not been implemented for six months) ***

1. Benchmarking is used to identify cutting-edge ERP techniques

2. We keep track of ERP developments related to our industry

3. Cross-functional groups meet regularly to discuss new uses for the ERP system

4. Internal groups meet regularly to share new methods of using the ERP system

5. ERP improvement suggestions are regularly collected from multiple employee levels

6. Business experiments are conducted to evaluate potential improvements in the way we use ERP.

7. ERP experimentation is encouraged even if the proposed improvement is unsuccessful.

8. External ERP experts are invited to suggest better ways to use the ERP system.

\section{Change Readiness}

*** Timeframe: four months after the ERP project has started $* * *$

1. Employees understand how they fit into the new ERP Entity

2. Employees have input into how their jobs will change with new ERP business processes.

3. Management actively works to alleviate employee concerns about ERP.

4. An ERP support group is available to answer concerns about ERP job changes

5. The roles of all employees under the ERP system have been clearly communicated

*** Timeframe: two months after the ERP has been implemented ***

6. The change readiness of employees impacted by the ERP system is regularly assessed

7. Employees are not prepared for a series of ERP-related changes as the system evolves (Note the "not")

8. ERP-focused changes to the employee reward system have been communicated

\section{J. Improved Business Performance}

*** Timeframe: 3 months AND 12 months after ERP has been implemented -- see each question.

If your ERP has been implemented for 12 or more months, please answer for both 3 months and 12 months.

*** Skip to the end if your ERP has not been implemented for three months ***

O. How long has your ERP been implemented? Months 
1. Company business processes have been rationalized through the use of the ERP system

2. Business flexibility has been diminished through the use of the ERP system

3. The ERP system allows for better control of business operating expenses

4. New market opportunities have been identified through the use of ERP

5. The ERP system has improved customer satisfaction

6. ERP Entity facilities have been rationalized due to information provided by the ERP system

7. The ERP system allows users to generate supply-chain schedules addressing customer needs.

8. The efficiency of the ERP Entity's supplier network has been improved

9. The efficiency of the procurement function has been improved

10. The efficiency of the distribution function has been improved

11. Business benefits have been realized from the reengineered ERP processes

For the final questions, please answer whether the following are better (7) or worse (1)

12. Internal integration across functions

13. Internal integration across lines of business

14. Overall organizational agility

15. External integration with suppliers

16. External integration with customers

Notes 